\title{
THE DYNAMICS AND DETERMINANTS OF SOCIAL CAPITAL IN THE EUROPEAN UNION AND NEIGHBOURING COUNTRIES ${ }^{1}$
}

\author{
Eve Parts ${ }^{2}$ \\ University of Tartu
}

\begin{abstract}
This empirical study investigates the dynamics and the determinants of social capital in Europe over the period 1990-2008, using empirical data from EVS. Methodologically, factor analysis and regression analysis are implemented. The analysis covers 20 Western-European countries, 10 new member states and $15 \mathrm{EU}$ neighbouring countries. Comparison of the levels of social capital showed that, with few exceptions, the levels of social capital are lower in Eastern Europe as compared to the old member states in Western Europe. Regression results of the determinants of social capital showed that most influential factors of social capital are education and satisfaction with democracy. It follows that investments in educational system and improving democratization processes could increase the level of social capital as an important factor of economic development.
\end{abstract}

Keywords: Social capital, Europe, old and new member states, neighbouring countries

JEL Classification: A13, O52, P20, Z13

\section{Introduction}

In current times of after-crisis, all countries are looking for remedies for how to renew the economic growth process and to cure the negative outcomes of the crisis in terms of decreased welfare and employment levels, increased uncertainty and pessimism, etc. Social capital is considered as one of the factors of economic development, which increases economic efficiency at national level through supporting cooperation and lowering transaction costs. At the level of individuals, social capital in could provide alternative forms of resilience at difficult times, including strengthening of social and family networks and community practices to foster solidarity when confronted by crises. Empirically, it has been shown that regions and countries with relatively high stocks of social capital seem to achieve higher levels of innovation and growth, as compared to societies of low trust and civicness (e.g. Knack and Keefer 1997, Ostrom 1999, Rose 1999, Kaasa 2009). In broader terms it can be said that social capital is like a "glue" to hold society together, to embrace socially active multilevel networks and practices, norms and values which have an impact on trust and relations among individuals, and also between individuals and the state. Conscious enhancement of social capital makes it

\footnotetext{
${ }^{1}$ This paper is written with the financial support from the FP7 project No. 266834 (SEARCH).

${ }^{2}$ Associate Professor in Economics, PhD, University of Tartu, Department of Economics and Business Administration, Narva Road 4 -A210, Tartu 51009, Estonia, e-mail: eve.parts@ut.ee.
} 
possible to reduce risks in society as well as instill confidence into citizens that expected long-term positive results of reforms in times of crisis will outweigh shortterm cuts in state budget and welfare provision. Especially trust - both institutional trust and generalized trust - are essential factor for carrying out changes and reforms necessary to overcome the crisis.

However, the levels of social capital tend to decrease in times of crisis. Also, there is evidence that the levels of social capital are lower in new member states and neighbouring countries as compared to old EU members. As such, the lack of social capital may be an important development obstacle in less-developed regions of Europe. Therefore, it is important to analyze the changes in the levels of social capital during the crisis, and specific reasons behind the (expectedly) decreased levels of social capital, which tend to lead to lower economic growth rates at national level and hamper citizens' resilience at the individual level.

Current study aims to compare the levels and dynamics of social capital in EU member state, and to examine the determinants of social capital comparatively in three country groups - old and new member states, and neighbouring countries - in order to find out whether there are differences between country groups regarding social capital formation. Additionally, specific reasons for lower level of social capital in Eastern European countries with communist background would be explored. Information obtained from this study could help to understand future developments regarding the possible changes in the levels of social capital in NMS-s and NC-s, and to formulate activities and policies which may lead to faster recovery from crisis and higher prosperity in these regions.

\section{Theoretical background}

Social capital, in its broadest sense, refers to the internal social and cultural coherence of society, the trust, norms and values that govern interactions among people and the networks and institutions in which they are embedded (Parts 2009). As an attribute of a society, social capital can be understood as a specific characteristic of social environment that facilitates people's cooperation. The key idea of this argument is that communities can provide more effective and less costly solutions to various principal-agent and collective goods problems than can markets or government interventions (Durlauf 2004). Also, social capital helps to reduce transaction costs related to uncertainty and lack of information. As such, it can be said that social capital gives "soft", non-economic solutions to economic problems.

Theoretical literature mostly agrees that social capital consists of different components, which are more or less interrelated. The elements of social interaction can be divided into two parts: structural aspect, which facilitates social interaction, and cognitive aspect, which predisposes people to act in a socially beneficial way. The structural aspect includes civic and social participation, while the cognitive aspect contains different types of trust and civic norms, also referred to as trustworthiness. Although there has been some inconsistency concerning the relative importance of the cognitive and structural aspects of social capital, it could be 
assumed that these two sides of the concept work interactively and are mutually reinforcing. For example, informal communication teaches cooperative behavior with strangers in order to achieve shared objectives, and the importance of common norms and related sanctions necessary to prevent opportunistic behavior. Another important outcome of being involved in different types of networks is that personal interaction generates relatively inexpensive and reliable information about trustworthiness of other actors, making thus trusting behavior less risky. On the other hand, pre-existing generalized, diffused interpersonal trust indicates the readiness of an actor to enter into communication and cooperation with unknown people. Based on these relationships, it could be shortly summarized that social interaction requires communication skills and trust, which, in turn, tend to increase through interpersonal collaboration. Therefore, various dimensions of social capital should be taken as complements, which all are related to the same overall concept of social capital. (Parts 2009)

In order to design policies which help to increase the levels of social capital, one should first know which factors determine these levels. The determinants of social capital can be divided into two groups:

- The psychological and socio-economic characteristics of individuals such as personal income and education, family and social status, values and personal experiences, which determine the incentive of individuals to invest in social capital.

- Contextual or systemic factors at the level of community/nation, such as overall level of development, quality and fairness of formal institutions, distribution of resources and society's polarization, and prior patterns of cooperation and trust.

Current study focuses on the individual-level determinants of social capital ${ }^{3}$, which are empirically studied, for example, by Alesina and Ferrara (2000), Van Oorschot and Arts (2005), Christoforou (2005), Halman and Luijkx (2006), Kaasa and Parts (2008), and others. Although the results of these empirical studies are not always uniform, some generalizations can be made concerning the determinants of different types of social capital.

Firstly, income and education seem to be most influential socio-economic factors of social capital. Empirical evidence shows that higher levels of income and education coincide with a strong probability for group membership and interpersonal trust from the part of individual (Knack and Keefer 1997, Denny 2003, Helliwell and Putnam 1999, Paldam 2000, and others). However, the exact causal mechanism behind this relationship is not clearly explained in the literature. For example, trust could be a product of optimism (Uslaner 1995, 2003) generated by high or growing incomes. Economic recession is expected to reduce optimism and thus also to decrease the level of institutional trust. Similarly, education may strengthen trust and civic norms, if learning reduces uncertainty about the behaviour of others, or if students are taught to behave cooperatively (Offe and Fuchs 2002, Soroka et al.

\footnotetext{
${ }^{3}$ These national-level determinants of social capital remain outside the scope of the current study, but they constitute likely part of the future research on this topic.
} 
2003). These processes can be self-reinforcing: if individuals know that higher education levels make others more likely to be trusting (and perhaps also more trustworthy), then they are in turn more likely to trust others (Helliwell and Putnam 1999). This implies that the returns to trusting behaviour are higher when the average levels of education increase. At the more general level, it has been suggested that both formal and informal education act as mediators of social values and norms between human generations (Montgomery 2000). It appears that such value transmission should not always be supportive to social capital generation education may foster individualistic and competitive attitudes and hence reduce the motivation for cooperation.

As regards to a positive relationship between education, income and participation in community and voluntary activities, there is no simple answer to the question what makes more educated individuals to participate and volunteer more often. One possibility is to consider volunteering as a consumption good, which increases one's non-material well-being and is influenced by the opportunity cost of consumption of this good (Brown and Lankford 1992). Since higher education is associated with a higher opportunity cost of time (equal to foregone earnings), negative effect of education on volunteering could be expected. However, volunteering usually takes place out of work time, so there may be little or no trade-off. Among other explanations, there is a possibility that participation activity, education and wages may be determined by common omitted factors. For example, some personal traits, such as openness, activity, curiosity and responsibility, ensure higher education and wage, and are prerequisites for active participation in community life at the same time.

Education and income are also often related to person's employment status. Oorschot et al. (2006) have shown that the negative effect of unemployment holds for a wide range of social capital components, whereas the effect is stronger in case of indicators of formal participation and weaker on general trust.

Besides income and education, several other social and demographic determinants like age, gender, marital status, number of children, and others seem to be important in determining social capital. However, these factors are less studied than aforementioned and also the empirical results and their explanations are varying (see, for example, Christoforou 2005, Fidrmuc and Gerxhani 2005, Halman and Luijkx 2006). Shortly summarizing, most models show positive impact of age on trust and formal networks, although there is also great support for non-linear relationship. Concerning gender, men tend to have significantly higher participation levels in formal networks. Women, instead, have more family-based social capital, they are more trustworthy and accept more likely social norms. At the same time, trust - especially institutional trust - has not been found to be much influenced by gender. Further, usually it is expected that married couples have less social capital than on average, as family life takes time and decreases the need for outside social relations (Bolin et al. 2003). Theoretically, having children could be expected to have a similar effect as marriage, but empirical evidence is not so clear. 
Some studies have also tested the impact of town size on the components of social capital. The results illustrate the effect of physical distance and possible anonymity on the pattern of socializing: on the one hand, living in a small or medium-sized town tend to decrease both formal and informal participation (Fidrmuc and Gerxhani 2005), while Alesina and Ferrara (2000) show to the contrary that people have less informal social contacts in larger settlements.

Finally, religiosity might influence social capital, mostly increasing informal networks, social norms and institutional trust but lowering general trust (which is replaced with trust in god). However, belonging into different religious denominations could give different results - it is believed that trust is lower in countries with dominant hierarchical religions like Catholic, Orthodox Christian or Muslim (Putnam et al 1993, La Porta et al 1997), while Protestantism associates with higher trust (Inglehart 1990, Fukuyama 1995) and norms (van Oorschot et al 2006). Similarly to religious doctrines, communist rule can be considered as an example of the effect of ideology. In general, an ideology can create social capital by forcing its followers to act in the interests of something or someone other than himself (Knack and Keefer 1997, Whiteley 1999).

Summing up, empirical analysis in the second part of the paper would be rather explorative, as there is not much uniform evidence concerning the effect of several social capital determinants, especially when distinguishing between country groups with different economic and historical backgrounds. ${ }^{4}$

Next, the specific features of social capital in post-communist countries are investigated. More specifically, following literature overview ${ }^{5}$ focuses on the possible reasons why the levels, sources and also outcomes of social capital might be different in Central and Eastern European (CEE) post-communist countries, as compared to other European societies with longer tradition of market economy and democracy. Generally, it has been suggested that the main reason of the low levels of social capital in CEE countries is related to the legacy of communist past, postcommunist transformation processes and backwardness in social development. More specifically, following aspects could be highlighted:

- Firstly, transition produces uncertainty which tends to decrease a sense of optimism about the future, as people do not feel that they have control over their own destinies - this, in turn, leads to lower generalized trust (Uslaner 2003).

- Secondly, post-communist transition resulted in a rapid destruction of dominant values (like ideological monism, egalitarianism, and collective property) and habits, the process which stimulates development of cynism and opportunism

\footnotetext{
${ }^{4}$ It should be noted that most previous analyses have paid no attention to the possible differences in social capital determinants in different countries. There are only few exceptions (i.e. Fidrmuc and Gèrxhani 2005, Kaasa and Parts 2008, Parts 2009), but no solid conclusions can be drawn on the basis of so few studies.

${ }^{5}$ More detailed insight into studies about social capital in CEE countries can be found in Badescu and Uslaner (2003).
} 
and thus creates negative social capital. (Štulhofer 2000) Another result of the value changes is that transformation societies are becoming more individualized: traditional family life is breaking down and individuals become more isolated in society.

- Thirdly, transition economies are usually characterized by high levels of poverty and unemployment, competition at the workplace, and strong primary concern for the family, which do not create a good environment for mutual trust among people, for rebuilding social ties and networks of cooperation (Bartkowski 2003).

- Fourth, social capital and cohesion are negatively affected by unequal income distribution, which resulted from destruction of the old state-sector middle class, before a new middle class could be established. Uslaner (2003: 86) suggests that links between the increase of economic inequality and the low levels of generalized trust may be different in the transitional countries compared to the West, because in former the past equality was not the result of normal social interactions and market forces, but rather enforced by the state.

Another set of explanations of the low trust and participation levels is directly related to the communist past of these countries. Perhaps most fundamental is that communism taught people not to trust strangers - the encompassing political control over daily life presented people with the acute problem of whom to trust and how to decide whether intensions of others were honest. Flap and Völker (2003) explain how people created niches in their personal networks consisting of strong ties to trustworthy others, which allowed an uncensored exchange of political opinions and which provided social approval. At the same time, weak provision networks existed, but these were based solely on economic shortage in command economy and did not evolve a basis for mutual trust. (Ibid) Rose et al (1997) explain the low trust levels as a result of an "hour-glass society" in which the population was divided into two groups - ordinary people and privileged "nomenclature" - both having strong internal ties at the level of family and close friends within the group but little interaction with other group. Therefore the social circles in transition economies would seem to be smaller and more closed than in market economies, where the positive association between social networks and generalised trust is higher (Raiser et al 2001). Similar explanations hold for low levels of organisational membership (see Howard 2003, Gibson 2003).

Explanations of the low level of institutional trust are also complicated. In transition economies, where institutional and political frameworks are only being constructed and changes in the political situation affects quite strongly the trust in institutions, the trust may vary significantly without showing a clear patterns of relationships to the quality of institutional settings and economic performance (Mateju 2002). Although most of the European post-communist states have democratic constitutions and institutions, the Western model of democracy which posits a trusting and active citizenry is not well established in these countries (Badescu and Uslaner 2003). As an example, although a high percentage of people vote in national elections in the transition countries, most voters distrust the politicians and parties for whom they 
have voted. This suggests that the culture of the new political elite is often not supportive of building bridges between society and its political institutions.

Interestingly, Uslaner (2003) points out that what separate transition and nontransition societies is largely the people's interpretation of their prior experiences under communism, not psychology. The regimes are very different and this clearly affects both trust and civic engagement, but the differences in regimes work through the same underlying motivations for trusting others and taking part in civic groups. As such, although the trend of low trust and nonparticipation throughout postcommunist Europe is unlikely to change rapidly, three are still possible mechanisms for improvement (Howard (2002, pp. 166-167):

1) Generational change - young post-communist citizens are less influenced by the experience of life in a communist system. However, this result is not certain, as socialization comes not only from the current institutional setting, but also from one's parents, teachers, and peers who still have strong personal experience of the communist past.

2) More active and supportive role on the part of the state, with notion that this support should be selective, as not all kind of organizations are beneficial for democracy and overall wellbeing.

3) Improving economic conditions - raising the actual standards of living of most ordinary people, so that they might have the economic means to be able to devote some time and energy to voluntary organizations, and possibly to contribute a donation or membership fee.

Based on the above, it can be suggested that policies aiming to shape individual experiences so as to increase trust and civic engagement are possible in postcommunist societies. Even if the preciousness of social capital in respect of achieving alternative development objectives is the subject of further investigation, completion of transformation processes and improvements in social development are expected to favour also increase in the levels of social capital in NMS and several less developed neighbouring countries.

\section{Data and methodology}

Empirical part of the current study covers both European Union member states and as many neighbouring countries as possible. As one of the aims of this study was to highlight the particular features of social capital in post-communist countries, total sample was divided into three groups of countries: (i) Western European countries $(\mathrm{WE})^{6}$ including 15 "old" EU members plus 5 other countries from the region, (ii) new member states (NMS) ${ }^{7}$ including 10 post-communist countries from Central

\footnotetext{
${ }^{6}$ Austria, Belgium, Cyprus, Denmark, Finland, France, Germany, Greece, Iceland, Ireland, Italy, Luxembourg, Malta, Netherlands, Norway, Portugal, Spain, Sweden, Switzerland, Great Britain

${ }^{7}$ Bulgaria, Czech Republic, Estonia, Hungary, Latvia, Lithuania, Poland, Romania, Slovak Republic, Slovenia
} 
and Eastern Europe (CEE) plus Cyprus and Malta, and (iii) 15 neighbouring countries $(\mathrm{NC})^{8}$, mostly from CIS and Balkan.

The data about social capital were drawn from the European Values Study (EVS, 2010). For the analysis of the determinants of social capital, the data from the latest wave were used: for most countries the indicators pertain to the year 2008, except for Belgium, Finland, the United Kingdom, Iceland, Italy, Sweden, and Turkey (2009). In order to analyse the dynamics of social capital over time, the latest data were compared to those of year 1990. As many European countries outside EU were not included in the earlier rounds of EVS survey, the analysis of the changes in social capital levels covers less countries - 14 from WE and 10 NMS.

As social capital is a multifaceted concept, it can be best described by different dimensions instead of one overall index. Based on the theoretical considerations and also the availability of certain social capital data for as many European countries as possible, it was reasonable to distinguish between four components of social capital - general trust, institutional trust, social norms and formal networks. Altogether, 12 initial indicators were extracted from EVS survey. In order to ensure the correct interpretation of the results, the scales were chosen so that larger values reflect a larger stock of social capital. Then, latent variables of social capital were constructed using confirmatory factor analysis. The results of the factor analysis are presented in Appendix 1. The percentages of total variance explained by the factors range from $52.76 \%$ to $81.43 \%$ and Kaiser-Meyer-Olkin (KMO) measures indicate the appropriateness of the factor models (values of the KMO measure larger than 0.5 are usually considered as acceptable). The country mean factor scores of social capital can be found in Appendix 2.

Next, country mean factor scores were calculated and the levels of social capital in 1990 and 2008 were compared. Finally, regression analysis was conducted in order to investigate and compare the determinants of social capital in all three country groups.

Concerning the determinants of social capital, this study covers only individual-level determinants of social capital, which are divided into two broader categories: 1) socio-demographic factors like gender, age, income, education, employment and marital status, number of children and town size; and 2) cultural and psychological factors including individualism, satisfaction with democracy and religiosity. All these indicators are also taken from the latest wave of EVS. Exact descriptions of these indicators together with measurement details can be found in Appendix 3.

\section{Empirical results and discussion}

Based on the individual-level factors of social capital components, country mean factor scores were calculated and saved as variables for further analysis (see

\footnotetext{
${ }^{8}$ Albania, Azerbaijan, Armenia, Bosnia-Herzegovina, Belarus, Croatia, Georgia, Moldova, Montenegro, Russian Federation, Serbia, Turkey, Ukraine, Macedonia, Kosovo
} 
Appendix 2). Comparison of the levels of social capital showed that in case of all social capital components, the levels were lower in NMS as compared to WE. However, in less developed NC-s institutional trust and social norms appeared to be stronger than in NMS, but lower than in WE (see Table 1).

Table 1. Mean factor scores by country groups

\begin{tabular}{|l|c|c|c|c|c|}
\hline $\begin{array}{l}\text { Country } \\
\text { group }\end{array}$ & Year & $\begin{array}{c}\text { General } \\
\text { trust }\end{array}$ & $\begin{array}{c}\text { Institutional } \\
\text { trust }\end{array}$ & $\begin{array}{c}\text { Formal } \\
\text { networks }\end{array}$ & $\begin{array}{c}\text { Social } \\
\text { norms }\end{array}$ \\
\hline \multirow{2}{*}{ WE } & 1990 & 0.247 & 0.068 & 0.094 & 0.016 \\
\cline { 2 - 6 } & 2008 & 0.261 & 0.157 & 0.199 & 0.098 \\
\hline \multirow{2}{*}{ NMS } & 1990 & -0.178 & -0.090 & -0.066 & -0.003 \\
\cline { 2 - 6 } & 2008 & -0.244 & -0.252 & -0.194 & -0.130 \\
\hline NC & 2008 & $-0.212^{*}$ & 0.055 & -0.209 & 0.036 \\
\hline
\end{tabular}

Source: author's calculations. * Without Belarus and Azerbaijan which have exceptionally high levels of general trust, the average of NC-s is -0.285 .

The results support previous findings that in post-communist countries institutional trust may not be related to the institutional quality which is expectedly higher in NMS than in NC. It can be suggested that in NMS-s citizens are more demanding for institutions and democratization because of more explicit comparisons with WE countries, and thus stand more critically to the decisions of institutions.

Next, the levels of social capital in 1990 and 2008 were compared. Based on the availability of the data, this analysis covered 14 Western-European countries and 10 new member states. In general, the average level of social capital has creased in NMS and increased in WE during the period 1990-2008. However, the experiences of individual countries were rather diverse concerning the changes in different components of social capital, so no strong generalisations can be made on the basis of country groups. Unfortunately there were no data of social capital changes for NC-s, but based on recent historical experience of NMS-s, there is a possibility that institutional trust and acceptance of social norms would decrease in neighbouring countries when overall economic situation improves, as it has happened in new member states. In this situation, it is highly important to ensure the effectiveness and fairness of formal institutions when implementing economic and political reforms, in order to withstand possible decrease in institutional trust.

At the final stage of empirical analysis, regression analysis was conducted in order to investigate the determinants of social capital. The results from pooled sample are presented in Table 2. It appeared that most influential factors of social capital are education and satisfaction with democracy. Therefore, investments in educational system and improving democratisation processes could increase the level of social capital. Social capital also associates positively with age, income, and having children, while there was negative relationship between social capital, town size and individualism. 
As can be seen, some of the factors analysed could not be easily affected by policies, while encouraging overall economic and social development would give contrary results: growing incomes and population ageing tend to increase social capital, while spreading individualism might decrease social capital.

Table 2. The results of the regression analysis (standardized regression coefficients, pooled sample)

\begin{tabular}{|c|c|c|c|c|}
\hline \multirow{2}{*}{$\begin{array}{l}\text { Independent } \\
\text { variables }\end{array}$} & \multicolumn{4}{|c|}{ Dependent variable } \\
\hline & $\begin{array}{c}\text { General } \\
\text { trust }\end{array}$ & $\begin{array}{c}\text { Institutional } \\
\text { trust }\end{array}$ & $\begin{array}{c}\text { Formal } \\
\text { networks }\end{array}$ & $\begin{array}{l}\text { Social } \\
\text { norms }\end{array}$ \\
\hline gender & $0.04 * * *$ & 0.01 & $-0.02 * *$ & $0.05 * * *$ \\
\hline age & $0.08 * * *$ & $0.02 * * *$ & 0.00 & $0.16 * * *$ \\
\hline income & $0.08 * * *$ & $0.04 * * *$ & $0.08 * * *$ & 0.01 \\
\hline education & $0.12 * * *$ & $0.02 * *$ & $0.11 * * *$ & -0.01 \\
\hline unemployed & $-0.03 * * *$ & -0.01 & -0.01 & $0.01 * *$ \\
\hline relationship & 0.00 & $-0.01 * *$ & $0.02 * * *$ & $-0.05 * * *$ \\
\hline children & 0.00 & $0.03 * * *$ & $0.03 * * *$ & $0.04 * * *$ \\
\hline size of town & 0.00 & $-0.03 * * *$ & $-0.06 * * *$ & $-0.03 * * *$ \\
\hline individualism & $-0.08 * * *$ & $-0.01 *$ & $-0.07 * * *$ & 0.01 \\
\hline democracy & $0.12 * * *$ & $0.49 * * *$ & $0.04 * * *$ & $0.04 * * *$ \\
\hline religiosity & $-0.03 * * *$ & $0.03 * * *$ & $0.03 * * *$ & $0.09 * * *$ \\
\hline $\mathrm{CEE}$ & -0.02 & $-0.08 * * *$ & $-0.06 * * *$ & $-0.20 * * *$ \\
\hline $\mathrm{NC}$ & $-0.05^{*}$ & $0.06 * *$ & $-0.07 * *$ & $-0.14 * * *$ \\
\hline WE & $0.13 * * *$ & 0.00 & 0.04 & $-0.14 * * *$ \\
\hline F-Statistic & $171.59 * * *$ & $481.63 * * *$ & $84.49 * * *$ & $99.64 * * *$ \\
\hline Durbin-Watson & 1.53 & 1.56 & 1.35 & 1.39 \\
\hline Adjusted R-square & 0.11 & 0.26 & 0.06 & 0.07 \\
\hline
\end{tabular}

Notes: $\mathrm{N}=18829$; regression coefficients higher than 0.1 are marked bold. $* * *$ significant at the 0.01 level, ** significant at the 0.05 level, * significant at the 0.10 level (two-tailed).

As the statistical significance of country group dummies (see Table 2) revealed that there are probably some differences between country groups, next the regressions were run separately for all three country groups. The results of this analysis can be found in Appendix Table A4. Following Table 3 highlights the relationships which had different signs of regression coefficients in different country groups. 
Table 3. Differences between country groups in regression results

\begin{tabular}{|c|c|c|c|}
\hline & $\begin{array}{c}\text { Institutional } \\
\text { trust }\end{array}$ & Formal networks & Social norms \\
\hline Age & $\begin{array}{l}\mathrm{WE}+ \\
\mathrm{NMS}+ \\
\mathrm{NC}-(\mathrm{ns})\end{array}$ & $\begin{array}{l}\text { WE + } \\
\text { NMS - (ns) } \\
\text { NC - }\end{array}$ & \\
\hline Income & $\begin{array}{l}\text { WE + } \\
\text { NMS + } \\
\text { NC - }\end{array}$ & & $\begin{array}{l}\text { WE + } \\
\text { NMS - } \\
\text { NC - }\end{array}$ \\
\hline Education & $\begin{array}{l}\text { WE + } \\
\text { NMS - } \\
\text { NC (ns) }\end{array}$ & & $\begin{array}{l}\mathrm{WE}+ \\
\mathrm{NMS}+ \\
\mathrm{NC}-\end{array}$ \\
\hline Individualism & $\begin{array}{l}\text { WE - } \\
\text { NMS - (ns) } \\
\mathrm{NC}+\end{array}$ & & $\begin{array}{l}\text { WE - } \\
\mathrm{NMS}+(\mathrm{ns}) \\
\mathrm{NC}+\end{array}$ \\
\hline
\end{tabular}

coefficient and " $n s$ " refers to insignificant relationship.

Source: author's generalisations on the basis of regression results presented in Appendix A4.

The only component of social capital which was influenced mostly similarly by supposed determinants in different country groups was general trust (as a small exception, having children had positive effect in WE but weak negative effect in NC and NMS). As can be seen from Table 3, most diverse results appeared when analysing the determinants of institutional trust and social norms. Both income and age associate with higher institutional trust in WE and NMS, while in NC-s the opposite holds. In case of individualism, just an opposite pattern can be observed. Education has also diverse effect on institutional trust: in WE those with higher education have more institutional trust, but in NMS they have less institutional trust (in NC-s this relationship was insignificant). These mixed results could be related to the differences in actual quality of institutions in different country groups, although theory suggested that in post-communist countries the relationship between institutional quality and institutional trust is not quite clear.

As regards social norms, both income and education have positive effect in WE and negative effect in $\mathrm{NC}$, while the effect of individualism is just opposite in these country groups. In new member states, the effects of the same determinants are mixed: education has positive effect on social norms similarly to western European countries, while regarding the effect of income and individualism NMS-s are more similar to neighbouring countries where higher income decreases the acceptance of norms (in case of individualism the regression coefficient is positive like in NC-s but insignificant).

Finally, age has different effect on participation in formal networks: in WE the number of connections increases with age while in $\mathrm{NC}$ older people participate less 
in formal networks. The latter could be explained by different past experiences under communist rule formal participation was mostly "forced" not voluntary and this could have generated unwillingness to join different organisations even after the collapse of old social order.

Summing up, it seems that the determinants of social capital are in accordance with theory only in WE countries and tend to be opposite in NC-s, while new member states with communist background are somewhere in between - in some aspects they are already more similar to more developed western European societies, while in others they still suffer from past communist rule.

\section{Conclusions}

Current study aimed to compare the levels and dynamics of social capital in EU old and new member states, and to examine the determinants of social capital comparatively in different country groups, in order to highlight problem areas regarding harmfully low levels of social capital in some countries or country groups, and to find possible policy solutions which help to increase social capital. As one of the tasks of this study was to highlight the particular features of social capital in post-communist countries, total sample was divided into three groups of countries: Western European countries including 15 "old" EU members plus 5 other countries from the region, new member states including 10 post-communist countries from Central and Eastern Europe plus Cyprus and Malta, and 15 neighbouring countries mostly from CIS and Balkan.

As social capital is a multifaceted concept, it can be best described by different dimensions instead of one overall index. Based on the theoretical considerations and also the availability of certain social capital data for as many European countries as possible, it was reasonable to distinguish between four components of social capital - general trust, institutional trust, social norms and formal networks. These components were derived on the basis of 12 initial indicators from European Values Study dataset using confirmatory factor analysis.

Firstly, country mean factor scores were calculated and the levels of social capital in 1990 and 2008 were compared. Comparison of the levels of social capital showed that in case of all social capital components, the levels were lower in NMS as compared to WE. During 1990-2008, the average level of social capital decreased in NMS and increased in WE. In less developed NC-s institutional trust and social norms appeared to be stronger than in NMS, but lower than in WE. Based on historical experience it could be suggested that, unfortunately, there is a possibility that institutional trust and acceptance of social norms would decrease in neighbouring countries when overall economic situation improves, as it has happened earlier in new member states. In this situation, it is highly important to ensure the effectiveness and fairness of formal institutions when implementing economic and political reforms, in order to withstand possible decrease in institutional trust. 
Secondly, regression analysis was conducted in order to investigate the determinants of social capital, which were divided into two broader categories: 1) sociodemographic factors like gender, age, income, education, employment and marital status, number of children and town size; and 2) cultural and psychological factors including individualism, satisfaction with democracy and religiosity. Most recent data from EVS round 4 were used, referring mostly to year 2008. Results of the regression analysis showed that most influential factors of social capital are education and satisfaction with democracy. Therefore, investments in educational system and improving democratisation processes could increase the level of social capital. Social capital also associates positively with age, income, and having children, while there was negative relationship between social capital, town size and individualism. As can be seen, some of the factors analysed could not be easily affected by policies, while encouraging overall economic and social development would give contrary results: growing incomes and population ageing tend to increase social capital, while spreading individualism might decrease social capital.

Regarding the limitations of this study, only individual-level determinants of social capital were explored, which did not explain all differences between country groups. Regarding the further research, it would be reasonable to supplement the analysis with additional national-level determinants of social capital, such as overall level of development, quality and fairness of formal institutions, distribution of resources and society's polarization, and prior patterns of cooperation and trust. Also, clustering countries instead of analysing pre-defined country groups could give some additional insight into the state of social capital as an important factor of economic development and welfare in Europe.

\section{References}

1. Alesina, A., Ferrara, E. (2000). The Determinant of Trust. - NBER Working Paper Series, No. 7621

2. Badescu, G., Uslaner, E. M. (eds) (2003). Social Capital and the Transition to Democracy. London and New York: Routledge

3. Bartkowski, J. (2003). Social Capital in Poland. - In: Badescu, G., Uslaner, E. M. (eds), Social Capital and the Transition to Democracy, pp. 184-199.

4. Bolin, K., Lindgren, B., Lindström, M., Nystedt, P. (2003). Investments in Social Capital - Implications of Social Interactions for the Production of Health. - Social Science \& Medicine, Vol. 56, pp. 2379-2390.

5. Brown, E., Lankford, H. (1992). Gifts of Money and Gifts of Time: Estimating the Effects of Tax Prices and Available Time. - Journal of Public Economics, Vol. 47, pp. 321-341.

6. Christoforou, A. (2005). On the Determinants of Social Capital in Greece Compared to Countries of the European Union. - FEEM Working Paper, No. 68.

7. Denny, K. (2003). The Effects of Human Capital on Social Capital: A CrossCountry Analysis. - The Institute for Fiscal Studies, Working Paper No. 16.

8. Durlauf, S. N., Fafchamps, M. (2004). Social Capital. - NBER Working Paper Series, No. 10485. 
9. EVS (2010). European Values Study 2008, 4th wave, Integrated Dataset. GESIS Data Archive, Cologne, Germany, ZA4800 Data File Version 2.0.0 (2010-1130) doi:10.4232/1.10188

10. Fidrmuc, J., Gèrxhani, K. (2005). Formation of Social Capital in Eastern Europe: Explaining Gap vis-à-vis Developed Countries. - CEPR Discussion Paper, No. 5068

11. Flap, H., Völker, B. (2003). Communist Societies, the Velvet Revolution, and Weak Ties: The Case of East Germany. - In: Badescu, G., Uslaner, E. M. (eds), Social Capital and the Transition to Democracy, pp. 28-45.

12. Fukuyama, F. (1995). Trust: The Social Virtues and the Creation of Prosperity. New York: The Free Press.

13. Gibson, J. L. (2003). Social Networks, Civil Society, and the Prospects for Consolidating Russia's Democratic Transition. - In: Badescu, G., Uslaner, E. M. (eds), Social Capital and the Transition to Democracy, pp. 120-139.

14. Halman, L., Luijkx, R. (2006). Social Capital in Contemporary Europe: Evidence from the European Social Survey. - Portuguese Journal of Social Science, Vol. 5, pp. 65-90

15. Helliwell, J. F., Putnam, R. D. (1999). Education and Social Capital. - NBER Working Paper, No. 7121.

16. Howard, M. M. (2002). The Weakness of Civil Society in Post-Communist Europe. New York: Cambridge University Press.

17. Howard, M. M. (2003). Why Post-Communist Citizens Do Not Join Voluntary Organizations? - In: Stolle, D., Hooghe, M. (eds), Generating Social Capital, pp. 101-120, Palgrave Macmillan.

18. Inglehart, R. (1990). Culture Shift in Advanced Industrial Society. Princeton: Princeton University Press.

19. Kaasa, A., Parts, E. (2008). Individual-level determinants of social capital in Europe. - Acta Sociologica, Vol. 51, No. 2, pp. 145-168.

20. Kaasa, A. (2009). Effects of Different Dimensions of Social Capital on Innovative Activity: Evidence from Europe at the Regional Level. - Technovation, Vol. 29, No. 3, pp. 218-233.

21. Knack, S., Keefer, P. (1997). Does Social Capital Have an Economic Payoff? A Cross-Country Investigation. - The Quarterly Journal of Economics, November, Vol. 112, No. 4, pp. 1251-88.

22. La Porta, R., Lopez-de-Silanes, F., Shleifer, A., Vishny, R. W. (1997). Trust in Large Organizations. - American Economic Review, Vol. 87, No. 2, pp. 333338.

23. Mateju, P. (2002). Social Capital: Problems of its Conceptualization and Measurement in Transforming Societies. Paper presented at the OECD-ONS Conference on Social Capital Measurement, London, UK.

24. Montgomery, John (ed) (2000). Values in Education: Social Capital Formation in Asia and the Pacific. Hollis, New Hampshire: Hollis Publishing Company

25. Offe, C., Fuchs, S. (2002). A Decline of Social Capital? The German Case. In: Putnam, R. (ed) Democracies in Flux: The Evolution of Social Capital in Contemporary Society. Oxford: Oxford University Press. 
26. Ostrom, E. (1999). Social Capital: A Fad or a Fundamental Concept? - In: Dasgupta, P., Serageldin, I. (eds), Social Capital. A Multifaceted Perspective. Washington, D.C.: The World Bank, pp. 172-214

27. Paldam, M. (2000). Social Capital: One or Many? Definition and Measurement. - Journal of Economic Surveys, Vol. 14, No. 5, pp. 629-653.

28. Parts, E. (2009). Social capital, its determinants and relations with economic growth: comparison of the Western European and Central and Eastern European countries. PhD dissertation, University of Tartu, 293p.

29. Putnam R.D., Leonardi, R., Nanetti, R. (1993). Making Democracy Work: Civic Traditions in Modern Italy. Princeton: Princeton University Press.

30. Raiser, M., Haerpfer, C., Nowotny, T., Wallace, C. (2001). Social Capital in Transition: A First Look at the Evidence. - EBRD Working Paper, No. 61.

31. Rose, R. (1999). What Does Social Capital Add to Individual Welfare? An Empirical Analysis of Russia. - The World Bank Social Capital Initiative Working Paper No. 15.

32. Rose, R., Mishler, W., Haerpfer, C. (1997). Social Capital in Civic and Stressful Societies. - Studies in Comparative International Development, Vol. 32, No. 3, pp. 85-111.

33. Rothstein, B., Stolle, D. (2002). How Political Institutions Create and Destroy Social Capital: an Institutional Theory of Generalized Trust. Retrieved from http://upload.mcgill.ca/politicalscience/011011RothsteinB.pdf. (01.07.2005)

34. Soroka, S. N., Helliwell, J. F., Johnston, R. (2003). Measuring and Modelling Trust. - In: Kay, F. and Johnston, R. (eds) Diversity, Social Capital and the Welfare State. Vancouver, BC: University of British Columbia Press.

35. Stulhofer, A. (2000). Dynamics of Social Capital in Croatia 1995-1999, The World Bank social capital homepage.

36. Uslaner, E. M. (2003). Trust and Civic Engagement in East and West. - In: Badescu, G. and Uslaner, E. M. (eds), Social Capital and the Transition to Democracy, pp. 81-94.

37. Van Oorschot, W., Arts, W. (2005). Social Capital of European Welfare States: the Crowding Out Hypothesis Revisited. - Journal of European Social Policy, Vol. 15, No. 5, pp. 5-26.

38. Van Oorschot, W., Arts, W., Gelissen, J. (2006). Social Capital in Europe: Measurement, and Social and Regional Distribution of a Multi-faceted Phenomenon. - Aalborg University, CCWS Working Paper, No. 44.

39. Whiteley, P. F. (1999). The Origins of Social Capital. - In: Van Deth, J. W., Maraffi, M. and Whiteley, P. (eds), Social Capital and European Democracy, pp 25-44. London: Routledge. 
Appendix 1. Indicators of social capital

\begin{tabular}{|c|c|c|c|c|}
\hline $\begin{array}{l}\text { Latent factor } \\
\text { of social } \\
\text { capital }\end{array}$ & Initial indicators & $\begin{array}{l}\text { Factor } \\
\text { loadings }\end{array}$ & $\begin{array}{l}\text { Variance } \\
\text { explained }\end{array}$ & KMO \\
\hline \multirow{3}{*}{ General trust } & $\begin{array}{l}\text { People can be trusted/cant be } \\
\text { too careful }\end{array}$ & -0.702 & \multirow{3}{*}{$60.76 \%$} & \multirow{3}{*}{0.635} \\
\hline & $\begin{array}{l}\text { Most of the time people try to } \\
\text { be helpful or mostly looking } \\
\text { out for themselves }\end{array}$ & 0.799 & & \\
\hline & $\begin{array}{l}\text { Most people try to take } \\
\text { advantage of you or try to be } \\
\text { fair }\end{array}$ & 0.831 & & \\
\hline \multirow{3}{*}{$\begin{array}{l}\text { Institutional } \\
\text { trust }\end{array}$} & Confidence in government & 0.875 & \multirow{3}{*}{$73.30 \%$} & \multirow{3}{*}{0.714} \\
\hline & Confidence in parliament & 0.848 & & \\
\hline & Confidence in political parties & 0.845 & & \\
\hline \multirow{2}{*}{$\begin{array}{l}\text { Formal } \\
\text { networks }\end{array}$} & $\begin{array}{l}\text { Unpaid work for different } \\
\text { voluntary organizations }\end{array}$ & 0.902 & \multirow{2}{*}{$81.43 \%$} & \multirow{2}{*}{0.500} \\
\hline & $\begin{array}{l}\text { Belonging into different } \\
\text { voluntary organizations }\end{array}$ & 0.902 & & \\
\hline \multirow{4}{*}{ Social norms } & $\begin{array}{l}\text { Not justified: cheating on } \\
\text { taxes }\end{array}$ & 0.764 & \multirow{4}{*}{$52.76 \%$} & \multirow{4}{*}{0.747} \\
\hline & $\begin{array}{l}\text { Not justified: avoiding fare in } \\
\text { public transport }\end{array}$ & 0.734 & & \\
\hline & $\begin{array}{l}\text { Not justified: claiming state } \\
\text { benefits }\end{array}$ & 0.710 & & \\
\hline & $\begin{array}{l}\text { Not justified: accepting a } \\
\text { bribe }\end{array}$ & 0.696 & & \\
\hline
\end{tabular}

Source: author's calculations on the basis of EVS. 
Appendix 2. Country mean factor scores of social capital, 2008

\begin{tabular}{|l|c|c|c|c|}
\hline Country & General trust & Institutional trust & Formal networks & Social norms \\
\hline Albania & -0.53 & -0.21 & 0.36 & -0.27 \\
Armenia & -0.33 & 0.09 & -0.40 & 0.06 \\
Azerbaijan & -0.41 & 0.89 & -0.15 & -0.16 \\
Austria & 0.24 & -0.21 & 0.03 & -0.15 \\
Belarus & 0.07 & 0.44 & -0.19 & -0.90 \\
Belgium & 0.21 & -0.01 & 0.20 & -0.14 \\
Bosnia & -0.24 & -0.31 & -0.39 & 0.12 \\
Herzegovina & & & & \\
Bulgaria & -0.45 & -0.74 & -0.30 & 0.33 \\
Croatia & -0.24 & -0.57 & -0.18 & -0.13 \\
Czech & -0.06 & -0.40 & 0.01 & -0.30 \\
Republic & & & & \\
Cyprus & -0.60 & 0.46 & -0.23 & -0.23 \\
Denmark & 1.13 & 0.62 & 0.91 & 0.45 \\
Estonia & 0.20 & -0.18 & -0.05 & 0.03 \\
Finland & 0.60 & 0.02 & 0.32 & 0.21 \\
France & 0.16 & -0.01 & -0.12 & -0.27 \\
Georgia & -0.07 & 0.12 & -0.46 & 0.22 \\
Germany & 0.25 & -0.17 & -0.14 & 0.11 \\
Great Britain & 0.46 & -0.32 & -0.05 & 0.30 \\
Greece & -0.54 & -0.27 & -0.29 & -0.32 \\
Hungary & -0.16 & -0.47 & -0.37 & 0.16 \\
Iceland & 0.83 & 0.04 & 0.73 & 0.26 \\
Ireland & 0.50 & 0.19 & 0.42 & -0.06 \\
Italy & -0.07 & -0.22 & 0.75 & 0.16 \\
Kosovo & -0.33 & 0.86 & 0.28 & 0.53 \\
Latvia & 0.09 & -0.43 & -0.17 & -0.34 \\
Lithuania & -0.23 & -0.28 & -0.27 & -0.46 \\
Luxembourg & 0.19 & 0.60 & 0.47 & -0.22 \\
Macedonia & -0.36 & 0.21 & -0.08 & 0.28 \\
Malta & -0.03 & 0.47 & -0.33 & 0.56 \\
Moldova & -0.44 & -0.04 & -0.23 & -0.11 \\
Montenegro & -0.21 & -0.08 & -0.29 & 0.20 \\
Netherlands & 0.71 & 0.29 & 1.14 & 0.23 \\
Norway & 0.97 & 0.45 & 0.31 & 0.17 \\
Poland & -0.04 & -0.43 & -0.42 & -0.25 \\
Portugal & -0.33 & -0.15 & -0.19 & 0.16 \\
Romania & -0.40 & -0.31 & -0.24 & -0.17 \\
Russian & 0.30 & 0.22 & -0.42 & -0.56 \\
Federation & & & & \\
Serbia & -0.35 & -0.61 & -0.25 & 0.25 \\
\hline
\end{tabular}


Appendix 2 continues ...

\begin{tabular}{|l|c|c|c|c|}
\hline Country & General trust & Institutional trust & Formal networks & Social norms \\
\hline Slovak & -0.31 & 0.25 & -0.28 & -0.37 \\
Republic & & & & \\
Slovenia & -0.01 & 0.18 & 0.14 & 0.07 \\
Spain & 0.13 & 0.04 & -0.34 & -0.07 \\
Sweden & 0.80 & 0.38 & 0.19 & -0.09 \\
Switzerland & 0.64 & 0.46 & 0.24 & 0.22 \\
Turkey & -0.53 & 0.29 & -0.41 & 0.60 \\
Ukraine & 0.10 & -0.57 & -0.38 & -0.04 \\
\hline
\end{tabular}

Source: author's calculations.

Appendix 3. Indicators of the determinants of social capital

\begin{tabular}{|l|l|}
\hline Indicator & Exact description and measurement \\
\hline Gender & $1=$ male, 2=female \\
\hline Age & continous scale (year of birth was asked in the survey) \\
\hline Income & monthly household income (x1000), corrected for ppp in euros \\
\hline Education & highest educational level attained respondent (8 categories) \\
\hline Unemployment & 1=yes, 0=no \\
\hline Married & having steady relationship (1=yes, 0=no) \\
\hline Children & how many children do you have \\
\hline Town size & size of town where interview was conducted (8 categories) \\
\hline Individualism & $\begin{array}{l}\text { people should stick to own affairs (1=disagree strongly ... } \\
5=\text { agree strongly) }\end{array}$ \\
\hline Democracy & $\begin{array}{l}\text { are you satisfied with democracy (1=not at all ... 4=very } \\
\text { satisfied) }\end{array}$ \\
\hline Religiosity & $\begin{array}{l}\text { are you a religious person }(1=\text { convinced atheist, 2=not } \\
\text { religious person, 3=religious person) }\end{array}$ \\
\hline
\end{tabular}




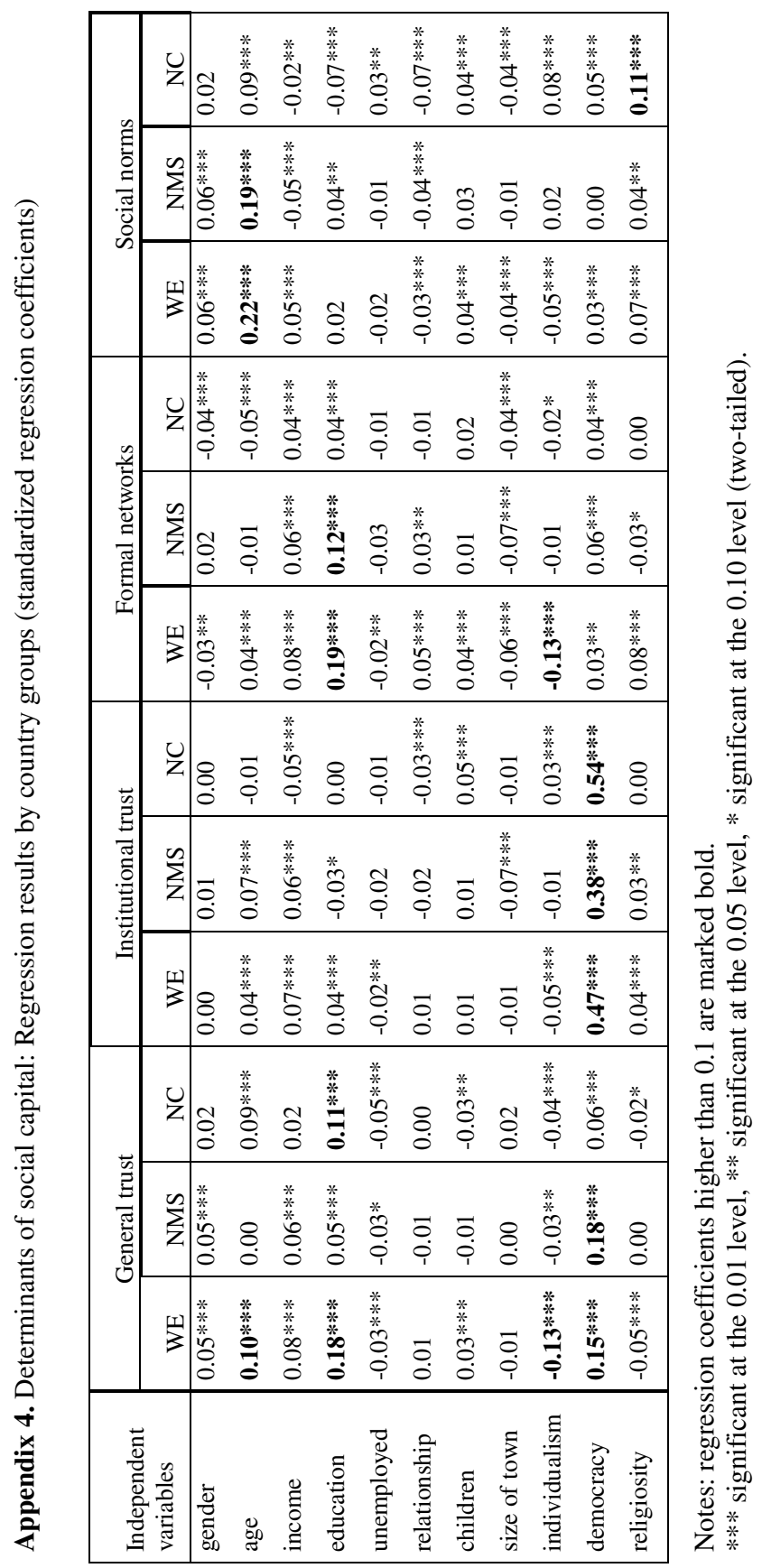




\title{
SOTSIAALKAPITALI DÜNAAMIKA JA DETERMINANDID: EL VANADE JA UUTE LIIKMESRIIKIDE NING NENDE NAABERRIIKIDE VÕRDLUS
}

\author{
Eve Parts ${ }^{1}$ \\ Tartu Ülikool
}

\section{Sissejuhatus ja teoreetiline raamistik}

Ülemaailmne majanduskriis on mõjutanud riike juba mitu aastat ja sundinud neid leidma lahendusi tekkinud sotsiaalsetele ja majanduslikele probleemidele nagu majanduskasvu aeglustumine ja riigivõla kasv; töötuse, vaesuse ja ebakindluse suurenemine jne. On ilmnenud, et traditsioonilised majanduspoliitilised meetmed üksi ei anna koheseid soovitud tulemusi, mis on muutnud inimesed rahulolematuks ja pessimistlikuks olukorra paranemise suhtes. Sellises olukorras on oluline roll alternatiivsetel, pehmematel meetmetel inimeste toimetuleku parandamiseks ja seeläbi ka majanduskasvu taastumise soodustamiseks. Üheks olukorra parandamise allikaks võiks olla sotsiaalkapitali rolli suurendamine. Sotsiaalkapitali saab vaadata nii riigi tasandil majanduskasvu soodustava tegurina, mis toimib läbi tehingukulude vähendamise ja koostöö tänu üldisele ja institutsionaalsele usaldusele ning tihedamatele ärivõrgustikele, kui ka indiviidi tasandil toimetulekut toetava tegurina, mis tõstab esile mitteformaalsed sotsiaalsed- ja peresuhted ning vabatahtliku kogukondliku tegevuse olukorras, kus materiaalsed tulud on vähenenud ning turu kaudu kõike vajalikku hankida pole võimalik. Selles kontekstis võib sotsiaalkapitali üldistatult käsitleda ühiskonda kooshoidva „liimina“, mis võimaldab raskete aegadega toime tulla nii indiviidide, kogukonna kui riigi tasandil. Sotsiaalkapitali, eriti üldise ja institutsionaalse usalduse tekkimise ja levimise soodustamine võimaldab vähendada kriisiga seonduvaid sotsiaalseid ja poliitilise riske ning aitab kodanikke veenda, et kriisimeetmete pikaajalised positiivsed mõjud jätkusuutliku majanduskasvu taastamisel kaaluvad üles lühiperioodil ilmnevad ebamugavused, mis seostuvad riigieelarve kärbete ja sotsiaalsete garantiide ajutise vähenemisega.

Teisalt on kirjanduse põhjal teada, et kriisi ajal kaldub sotsiaalkapitali tase ühiskonnas sageli vähenema. Seejuures sõltub riikide kogemus ka nende üldisest arengutasemest ja ajaloolisest taustast - statistika näitab, et Euroopa idapoolsetes liikmesriikides ja naabermaades (eriti kommunistliku režiimi taustaga riikides) on sotsiaalkapitali tase madalam kui Lääne-Euroopas, kujutades endast olulist takistust majanduskasvu taastumisel ja inimeste igapäevase toimetuleku tagamisel. Siit tulenevalt on oluline uurida, kuidas täpsemalt on sotsiaalkapitali tase Euroopas viimase kriisi käigus muutunud ja millised tegurid on neid muutusi enim mõjutanud.

\footnotetext{
${ }^{1}$ Dotsent, PhD, Tartu Ülikool, majandusteaduskond, Narva mnt. 4 - A210, Tartu 51009, Eesti, e-mail: eve.parts@ut.ee.

Käesolev artikkel on valminud Euroopa Komisjoni 7. Raamprogrammi projekti nr. 266834 (SEARCH) toetusel.
} 
Käesoleva uurimuse eesmärgiks on välja selgitada sotsiaalkapital taseme muutused Euroopas perioodil 1990-2008 ning hinnata sotsiaalkapitali taset mõjutavaid tegureid võrdlevalt kolmes riikide grupis: EL-i vanades liikmesriikides, uutes liikmesriikides ning idapoolsetes naaberriikides. Kuna kahes viimases grupis on paljud riigid kommunistliku ajalooga, siis uuritakse eraldi ka selle režiimi võimalikku mõju sotsiaalkapitali formeerumisele. Analüüsi tulemused peaksid andma olulist infot selle kohta, milliste poliitikate rakendamine on mõttekas ja vajalik sotsiaalkapitali kui olulise arenguteguri võimaluste paremaks ärakasutamiseks majanduskriisist taastumise perioodil.

\section{Empiirilised tulemused}

Artiklis läbiviidud empiiriline analüüs põhineb Euroopa Väärtushinnangute Uuringu (EVS - European Values Study) indiviidi tasandi andmetel. Sotsiaalkapitali kui mitmedimensioonilise nähtuse mõõtmiseks kasutati kinnitavat faktoranalüüsi, mille abil moodustati andmebaasist teooria põhjal väljavalitud 12 algnäitajast neli sotsiaalkapitali faktorit: üldine usaldus, institutsionaalne usaldus, formaalsed võrgustikud ja sotsiaalsete normide järgimine. Edasiseks analüüsiks arvutati indiviidi tasandi faktorite keskmistena välja sotsiaalkapitali komponentide hinnangud riigi tasandil. Muutusi sotsiaalkapitali tasemes perioodil 1990-2008 vaadeldi võrdlevalt kahes riikide grupis, mille moodustasid 14 Lääne-Euroopa (WE - Western Europe) riiki ning 10 EL-i uut liikmesriiki Ida-Euroopast (NMS - new member states). Tulemused kinnitasid oletust, et Lääne-Euroopas on sotsiaalkapitali tase kõrgem kui Ida-Euroopas, kusjuures perioodil 1990-2008 on lõhe nende kahe riikide grupi vahel suurenenud. Kui kaasata 2008.a. andmetel sotsiaalkapitali tasemete võrdlusesse ka EL-i naaberriigid ( $\mathrm{NC}$ - neighbouring countries), mis on madalama arengutasemega ning paljudel juhtudel samuti kommunistliku režiimi taustaga nagu Ida-Euroopa riigid, siis ilmnevad mitmed huvitavad tendentsid (vt. tabel 1).

Tabel 1. Sotsiaalkapitali komponentide faktorskoorid riikide gruppide lõikes

\begin{tabular}{|l|c|c|c|c|c|}
\hline $\begin{array}{l}\text { Riikide } \\
\text { grupp }\end{array}$ & Aasta & $\begin{array}{c}\text { Üldine } \\
\text { usaldus }\end{array}$ & $\begin{array}{c}\text { Institutsionaalne } \\
\text { usaldus }\end{array}$ & $\begin{array}{c}\text { Formaalsed } \\
\text { võrgustikud }\end{array}$ & $\begin{array}{c}\text { Sotsiaalsed } \\
\text { normid }\end{array}$ \\
\hline \multirow{2}{*}{ WE } & 1990 & 0.247 & 0.068 & 0.094 & 0.016 \\
\cline { 2 - 6 } & 2008 & 0.261 & 0.157 & 0.199 & 0.098 \\
\hline \multirow{2}{*}{ NMS } & 1990 & -0.178 & -0.090 & -0.066 & -0.003 \\
\cline { 2 - 6 } & 2008 & -0.244 & -0.252 & -0.194 & -0.130 \\
\hline NC & 2008 & $-0.212^{*}$ & 0.055 & -0.209 & 0.036 \\
\hline
\end{tabular}

* Kui jätta NC valimist välja Valgevene ja Aserbaidžan kui erandlikult kõrge üldise usalduse tasemega rigid, siis on NC riikide keskmine üldine usaldus -0.285.

Allikas: autori arvutused EVS põhjal.

Esiteks, üldise usalduse ja formaalsete võrgustike puhul kehtib eeldatud seaduspära, mille kohaselt kõrgema tulutasemega NMC-des on rohkem sotsiaalkapitali kui vaesemates naaberriikides. Võrreldes aga institutsionaalse usalduse ja sotsiaalsete 
normide näitajaid, on tulemus vastupidine - need sotsiaalkapitali komponendid on NC-des suurema väärtusega kui uutes liikmesriikides. Ilmselt tuleneb see kommunistlikust pärandist ja inimeste väiksemast julgusest valitsuselt ühiskonda edasiviivaid reforme nõuda - ollakse (vähemalt avalikult) pigem oma tegelikku arvamust ning rahulolematust enda teada hoidvad. Küll aga võib Ida-Euroopa uute liikmesriikide näitel oletada, et aja jooksul muutuvad inimesed julgemaks ja nõudlikumaks, mis võib paraku tähendada institutsionaalse usalduse (ajutist) vähenemist EL-i naaberriikides. Sellele tendentsile vastuseismiseks on äärmiselt oluline tagada riiklike institutsioonide toimimise efektiivsus ja usaldusväärsus, mis on aga keeruline arvestades, et kriisi tagajärgedega toimetulekuks vajalikud reformid on sageli valulikud.

Tabel 2. Sotsiaalkapitali mõjurid: regressioonanalüüsi tulemused (standardiseeritud regressioonikoefitsiendid)

\begin{tabular}{|c|c|c|c|c|}
\hline \multirow{2}{*}{$\begin{array}{l}\text { Sõltumatud } \\
\text { muutujad }\end{array}$} & \multicolumn{4}{|c|}{ Sõltuv muutuja } \\
\hline & $\begin{array}{l}\text { Üldine } \\
\text { usaldus }\end{array}$ & $\begin{array}{c}\text { Institutsionaalne } \\
\text { usaldus } \\
\end{array}$ & $\begin{array}{l}\text { Formaalsed } \\
\text { võrgustikud }\end{array}$ & $\begin{array}{c}\text { Sotsiaalsed } \\
\text { normid }\end{array}$ \\
\hline Sugu & $0.04 * * *$ & 0.01 & $-0.02 * *$ & $0.05 * * *$ \\
\hline Vanus & $0.08 * * *$ & $0.02 * * *$ & 0.00 & $0.16^{* * *}$ \\
\hline Sissetulek & $0.08 * * *$ & $0.04 * * *$ & $0.08 * * *$ & 0.01 \\
\hline Haridus & $0.12 * * *$ & $0.02 * *$ & $0.11 * * *$ & -0.01 \\
\hline Hõive staatus & $-0.03 * * *$ & -0.01 & -0.01 & $0.01 * *$ \\
\hline Lähisuhe & 0.00 & $-0.01 * *$ & $0.02 * * *$ & $-0.05 * * *$ \\
\hline Lapsed & 0.00 & $0.03 * * *$ & $0.03 * * *$ & $0.04 * * *$ \\
\hline Elukoha suurus & 0.00 & $-0.03 * * *$ & $-0.06 * * *$ & $-0.03 * * *$ \\
\hline Individualism & $-0.08 * * *$ & $-0.01 *$ & $-0.07 * * *$ & 0.01 \\
\hline Demokraatia & $0.12 * * *$ & $0.49 * * *$ & $0.04 * * *$ & $0.04 * * *$ \\
\hline Religioossus & $-0.03 * * *$ & $0.03 * * *$ & $0.03 * * *$ & $0.09 * * *$ \\
\hline NMS & -0.02 & $-0.08 * * *$ & $-0.06 * * *$ & $-0.20 * * *$ \\
\hline $\mathrm{NC}$ & $-0.05^{*}$ & $0.06 * *$ & $-0.07 * *$ & $-0.14 * * *$ \\
\hline WE & $0.13 * * *$ & 0.00 & 0.04 & $-0.14 * * *$ \\
\hline F-Statistic & $171.59 * * *$ & $481.63 * * *$ & $84.49 * * *$ & $99.64 * * *$ \\
\hline Durbin-Watson & 1.53 & 1.56 & 1.35 & 1.39 \\
\hline Adjusted R-square & 0.11 & 0.26 & 0.06 & 0.07 \\
\hline
\end{tabular}

Märkused: $\mathrm{N}=18829$. $* * *$ seos on statistiliselt oluline nivool $0.01, * *$ oluline nivool $0.05, *$ oluline nivool 0.10 .

Empiirilise analüüsi teiseks uurimisküsimuseks oli sotsiaalkapitali mõjurite väljeselgitamine, milleks viidi läbi regressioonanalüüs EVS-i kõige värskemate, 2008. aasta andmetega. Sellesse analüüsietappi oli kaasatud $20 \mathrm{WE}, 10 \mathrm{NMS}$ ja 15 
NC riiki. Teooriast lähtuvalt vaadeldi kahte sotsiaalkapitali mõjurite gruppi indiviidi tasandil: 1) sotsiaal-demograafilised tegurid nagu vanus, sugu, haridus, sissetulek, hõive ja kooselu staatus, laste olemasolu ja elukoha suurus, ning 2) kultuurilised ja psühholoogilised tegurid nagu individualism, rahulolu demokraatia arengutasemega ning religioossus. Regressioonanalüïsi tulemused on toodud tabelis 2 .

Tabelist 2 on näha, et olulisimad sotsiaalkapitali mõjurid on haridus ja rahulolu demokraatiaga. Seega on sotsiaalkapitali suurendamiseks olulised investeeringud haridussüsteemi ja ühiskonna üldine demokratiseerimine. Väiksemat positiivset seost sotsiaalkapitaliga omasid ka vanus, sissetulek ja laste olemasolu, samas kui individualism ning elamine suuremas linnas või asumis pigem pärsivad sotsiaalkapitali teket. Viimatinimetatud tegurite puhul on raske välja tuua konkreetseid poliitikasoovitusi - üldise majandusarengu soodustamine suurendab ka sissetulekuid, kuid reeglina kaasneb sellega individualismi kasv, väiksem laste arv perekonnas ning inimeste koondumine suurematesse linnadesse, kus on tasuvamad töökohad. Positiivsema poole pealt võib välja tuua, et rahvastiku vananemine arenenud riikides peaks sotsiaalkapitali loomisele kaasa aitama.

Tabel 3. Riikide gruppide erinevused

\begin{tabular}{|c|c|c|c|}
\hline & $\begin{array}{c}\text { Institutsionaalne } \\
\text { usaldus }\end{array}$ & $\begin{array}{l}\text { Formaalsed } \\
\text { võrgustikud }\end{array}$ & $\begin{array}{c}\text { Sotsiaalsed } \\
\text { normid }\end{array}$ \\
\hline Vanus & $\begin{array}{l}\mathrm{WE}+ \\
\mathrm{NMS}+ \\
\mathrm{NC}-(\mathrm{ns})\end{array}$ & $\begin{array}{l}\mathrm{WE}+ \\
\mathrm{NMS}-(\mathrm{ns}) \\
\mathrm{NC}-\end{array}$ & \\
\hline Sissetulek & $\begin{array}{l}\mathrm{WE}+ \\
\mathrm{NMS}+ \\
\mathrm{NC}-\end{array}$ & & $\begin{array}{l}\text { WE + } \\
\text { NMS - } \\
\text { NC - }\end{array}$ \\
\hline Haridus & $\begin{array}{l}\text { WE + } \\
\text { NMS - } \\
\text { NC (ns) }\end{array}$ & & $\begin{array}{l}\mathrm{WE}+ \\
\mathrm{NMS}+ \\
\mathrm{NC}-\end{array}$ \\
\hline Individualism & $\begin{array}{l}\text { WE - } \\
\text { NMS - (ns) } \\
\mathrm{NC}+\end{array}$ & & $\begin{array}{l}\text { WE - } \\
\mathrm{NMS}+(\mathrm{ns}) \\
\mathrm{NC}+\end{array}$ \\
\hline
\end{tabular}

Allikas: autori üldistused eraldi riikide gruppides läbiviidud regressioonanalüüsi põhjal.

Kuna tervikvalimiga läbiviidud analüüsis osutusid erinevaid riikide gruppe tähistavad fiktiivsed muutujad mitmel juhul statistiliselt oluliseks, viidi regressioonanalüüs läbi ka eraldi iga grupi andmetega. Ainsaks sotsiaalkapitali komponendiks, mille mõjurid on kõigis riikide gruppides sarnased (st samasuunalised, ehk kõik regressioonikoefitsiendid on sama märgiga), osutus üldine usaldus. Kõigi ülejäänud komponentide puhul ilmnes ühe või enama mõjuri osas erinevusi. Peamised erinevused tulemustes võtab kokku tabel 3. Kui formaalsete 
võrgustike puhul oli erinev vaid vanuse mõju (positiivne WE-s ja negatiivne NC-s), siis institutsionaalse usalduse ja sotsiaalsete normide puhul oli erinevusi märksa rohkem. Institutsionaalse usalduse mõjuritest olid eeldatule vastupidised vanuse ja sissetuleku negatiivne mõju NC-s, hariduse negatiivne mõju NMS-s ning individualismi positiivne mõju NC-s. Sotsiaalsete normide puhul oli tavapärasele vastupidine sissetuleku positiivne mõju WE-s, hariduse negatiivne mõju NC-s ning individualismi positiivne mõju nii NMS kui NC riikides.

\section{Kokkuvõte}

Kokkuvõtteks võib öelda, et sotsiaalkapitali taseme erinevused vaadeldud riikide gruppides vastavalt üldjoontes teoorias eeldatule, mille kohaselt kasvab sotsiaalkapitali tase koos riigi üldise arengutasemega. Erandiks osutusid institutsionaalne usaldus ja sotsiaalsete normide järgimine, mille suhteliselt kõrge taseme põhjuseks majanduslikult ja ühiskondlikult vähemarenenud EL-i naabermaades võib pidada nende varasema kommunistliku režiimi pärandit. Sotsiaalkapitali mõjureid uurides selgus, et varasema kirjanduse põhjal üldistatud seaduspärad kehtivad vaid Lääne-Euroopa riikides ning EL-i naabermaades on seosed pigem vastupidised. Ida-Euroopa riigid, sh. Eesti jäävad nende kahe äärmuse vahele: mõnes aspektis on meil sotsiaalkapitali tekkimisega seotud protsessid sarnased Lääne-Euroopale, kuid teatud valdkondades ilmnevad veel kommunistliku mineviku järelmõjud. Küll aga võib üldistada, et parimad meetmed sotsiaalkapitali sihipäraseks tugevdamiseks on kõikjal seotud hariduse ja demokraatia edendamisega. 